\title{
Hyperflexibility \\ A feature of e-commerce organisations
}

Jolanta Bieńkowska Ph.D., Department of Management, Faculty of Management, University of Lodz

Prof. Czesław Sikorski Department of Management, Faculty of Management, University of Lodz

\section{Introduction}

When analyzing the management of modern organizations we can abstract two exogenous factors that crucially determine the way they operate. The first one is the technique. Its constant and dynamic development has contributed to the creation of a new market plane, which is the electronic market. This happened as a result of development of the Internet and the possibility to exploit its potential in the sphere of business. The second factor is the market and the ever changing specifics of the game played on it. Persistent for decades, ever-increasing market saturation led to a change in relations between its participants from competitive - to hypercompetitive, characterised by a violent struggle and strenuous search for new market niches. E-commerce comes forth by giving greater opportunities to the action than in the traditional market due to lack of territorial boundaries. However, this situation makes it necessary to change the way of managing organizations towards the shaping of the attribute such as hyperelasticity of the organization, the ability to simultaneously use a variety of organizational solutions in order to increase the effectiveness of operating - the 
conjunction and not the alternative.

The following article is part of the author's theoretical concept of evolution of management. It was created as a result of in-depth literature studies of changes taking place in the functioning of the organization since the birth of management science under the influence of dynamic technical development and ongoing changes in the rules of the market game. The issue of organizational management in the Information Age is the last currently occurring stage of evolution. The observations and conclusions contained in the article were based on the assumptions that the dominant determinant of the organizational management operating on the market for e-commerce is the organizational culture, and that the basis for the effective operation of the organization is Hyperelasticity. This concept requires the operationalization on the basis of management science, because it is used most often without a precise explanation as a higher degree of flexibility. The article hypothesized that the organization's success in the market of e-commerce depends on the ability to use foreign resources through joint projects with other organizations. Whereas the aim of this article is to identify the factors determining the management of organizations in the market of e-commerce and the conceptualization of the notion of hyperelasticity of the organization.

\section{The e-commerce market}

The term e-business was introduced into the management vocabulary in 1995 by IBM. It referred to the transformation of key business processes, which was effected by the advent of internet technologies (Spencer 2004, p. 58, 54) and owing to which the contacts between organisation and their clients, suppliers, and other business partners became virtual in sales, promotion, distribution, orders, customer service, supplies, payments and other areas (Żurak-Owczarek 2013, p.15). The commerce platform where these processes occur is called the e-commerce market. It is a market that is still developing, but at the same time it is characterised by high dynamics, among others in Poland (Chrabowski, Wiśniewska, Nisztuk et al. 2015, p. 3), where the consumers more and more often are choosing to shop on-line (CBOS 2014, p. 1). The profits on the e-commerce market in Poland reached 27 billion zlotys in 2014 (Mróz 2015). In the European Union it is currently one of the priority areas for business activities (Świeboda, Petru 2012, p. 3). Additionally, more and more people are interested in opening e-commerce businesses as the barriers to entry are much lower than in case of a traditional market (Kozielski 2013, p. 119). This creates favourable conditions 
for growth of microenterprise, which is treated as one of the significant methods of fighting unemployment (Świeboda, Petru 2012, p. 3). The participants in e-commerce include not only micro- and small enterprises, although these are seen as the ones holding most growth potential for this market, but also larger businesses, which diversify the output market. However, the virtualisation of the $\mathrm{B} 2 \mathrm{C}$ relations (business-to-consumer) is not the sole factor vital for economic development. The other, equally crucial dimension is B2B (business-to business), which is nothing else than the performance of cooperation relations with the help of electronic media. For this purpose companies use business services centres offering accounting and finance, IT, human resources, customer service, supplies chain, or administration services (Michalak 2012, p. 75), which successfully execute the concept of outsourcing which resulted from the implementation of IT solutions in transaction processes (Szymański 2013, p. 48).

The development opportunities for the e-commerce market germinated as a result of changes in interaction rules between the owners of internet services and their users. This change meant mainly the active and predominant involvement of the users in creating the content for the services. The Web 2.0 services, aimed at fulfilling the need for information, are used as opinion exchange platforms and support for the current and future entrepreneurs. This in turn generates new business projects and ventures. The Internet communities that grow around these services can be used to implement on-line business models whose purpose is to organise markets, bring buyers and sellers together, facilitating transactions, as well as creating a virtual community that establishes user loyalty.

The e-commerce market differs in essence from a traditional market where the market playing field can be classified depending on the customer, product, or the geographical area. In a traditional market, the various restrictions in the activities of organisations dominate over the opportunities. In the industrial age, a business organisation was operating on a comparatively small market due to an unvaried product range. On that market, the competition was usually less aggressive as the market was highly receptive. Later, the introduction of new products and development of new markets were accompanied by dynamic competition that also entailed new restrictions of business activities. It is the reverse on the electronic market: the opportunities dominate over the limitations. At the same time, the scale of these opportunities appears equally high as the number of possible configurations in a kaleidoscope. This is caused by the fact that the e-commerce market is not defined by territory, changeable, and provides almost limitless possibilities for cooperation and employment of foreign resources. 


\section{The conditions where organisations operate}

The growth of the Internet created a virtual space with new communication possibilities which enabled the development of the so-called Internet entrepreneurship. The network environment has a great potential for generating economic benefit, it acts as a stimulant to the activity of potential entrepreneurs, and facilitates rapid spreading of innovations (Eoboda, Mącik 2005, p. 12). Continuous innovation and improvement of subsequent product versions is crucial to e-commerce.

This leads to a fundamental change in terms of the attitude of market players. Instead of continually reacting to whatever is happening on the market, as in case of traditional markets, new or niche markets can be created on the existing one. The e-commerce market is fluid, forever reinventing itself as a result of the agreements and the creation of temporary network structures that combine elements of various organisations for the purpose of completing joint projects. The concept that accurately reflects the nature of the gameplay on the e-commerce market is hypercompetition. The attempts to define that term refer to the necessity to take aggressive, rapid, and decisive action against other market participants (D'aveni 2010, p. 216). A prerequisite to competing efficiently for market position is the ability to implement various solutions that will be the most beneficial in the light of the current decisions. Consequently, there is a necessity to make frequent, rational choices from the possible and available solutions. It is also worth noting that, on the e-commerce market, it is impossible to closely monitor the activities of competitors, some of whom arise and disappear quite unexpectedly. Therefore a much wider scope of competitors must be considered (Hartman, Sifonis, Kador, 2001, p. 52).

When debating the conditions for market play, attention must be paid to the features which differentiate e-business from traditional enterprise that may impact the choice of strategy. The first is the limitless territory of the market. The market game can be played between competitors located in different parts of the globe, which is especially frequent in the B2B sector. The outsourcing service provider is selected on the basis of optimum offer criteria - the quality-to-price ratio, and not the geographical distance. The same indicator determines the potential ease with which the markets can change, the possibility to create new and niche markets (Majewski 2007, p. 49), as well as the relative ease of reaching customers with specific preferences who are dispersed throughout the world.

Therefore, on the e-commerce market, the organisations must be always ready to react to any unforeseen changes in customer behaviour and the unpredictability 
of the market. Moreover, they must accept the fact that, on the basis of the analysis of their current experience, businesses cannot effectively make forecasts, and establishing objectives does not mean that it is possible to prepare an optimal action plan to reach these objectives (Trompenaars, Hampden-Turner 2002, p. 167). The great challenge is to develop the capacity to continually improve the operation in order to achieve a permanent adaptive ability (Koźmiński 2013, p. 55) thanks to a combination of "loose" and "tight" properties (Peters, Waterman 2000 , p. 469), that is the extreme attitudes that enable the correct reaction to a changing situation in a market environment.

\section{Organisation's modus operandi}

In these circumstances, the observation made by M. Crozier (1993) appears very accurate - that the organisation theory must reflect upon the ability of groups of people to cooperate within far more complex systems than ever before and upon the best applications of this ability (M. Crozier 1993, p. 40). In order to be efficient in various market environments an organisation must have the ability to absorb such variety. It is possible only when the organisation itself has the requisite variety. This principle, according to S. Beer (1974), is the fundamental law of designing a viable organisation (Beer 1974, p. 93). The variety of organisational solutions should be understood both in terms of time and space. Variety in spatial terms means using various operating principles in various areas of activity. Whereas temporal variety implies the change of these principles in time - for example, the alternating periods of stability and flexible organisational solutions. It could be said that this is a triumph of conjunction over alternatives in terms of organisations' modus operandi. This manner of operation cannot be either stable or flexible, but must be both stable and flexible depending on the place and time.

In connection with the above, the relatively fixed organisational form as the subject of management appears to be disappearing on the e-commerce market. It is being replaced by a project implemented in the temporary, network structure which connects various organisations or their parts and their resources. Thus the fixed reference point is not longer the organisation, but the individual - the entrepreneur or a group of such people who continually search for associates in order to carry out various projects and who, for this purpose, create the necessary structures and use their own as well as foreign resources. When managing and organisation on the one hand one is striving to make it as lean and as specialised as possible, while at the same time trying to establish cooperation 
with various partners in order to undertake different ventures - that is to make their operations more universal. An organisation understood as a component of a network, a fixed module that can be combined with other diverse networks is different from a network as a temporary organisation used for the implementation of a specific project. T. Peters (1993) points out the apparent paradoxes in the ways organisations function in network structures. On the one hand, these organisations are becoming smaller, relinquishing the performance of many tasks and outsourcing them to subcontractors, on the other hand - they are becoming bigger by participating in the vast network of global cooperation. While they are internally disintegrating, dividing into sets of smaller organisational units which operate independently in their environment, at the same time they are also for more strongly integrated internally due to the need to exchange resources and information intensively between these units (Peters 1993, 473). This emphasises the quickly progressing dysfunction of the organisation as a structure with clearly defined objectives and area of operation. Managing an organisation on the e-commerce market means managing a business where one is continually searching for opportunities for beneficial allocation of own resources and effective use of foreign resources. Business management focuses on the relations between the organisation and its environment, and requires knowledge of the market, skills in project management, creativity in problem solution, effective negotiations with business partners, in short - skills in horizontal cooperation and not the creation of hierarchical relationships. This leads to an essential change in management which involves distribution of organisational power. It is clearly visible in the definition of modern leadership formed by A.K. Koźmiński (2004, p. 151) - "When talking about leadership, we mean a specific and crucial resource of an organisation, an element of its social potential: the sum of abilities, skills, and talents of one group of the organisation's members to influence the other groups in order to achieve the objectives established by that organisation." Understood in these terms, there is no leader defined as an individual endowed with special traits that enable them to influence the behaviour of others. Here leadership skills and talents are dispersed and varying in time. The members of an organisation influence one another in various situations and circumstances when pursuing their organisation's objectives.

As has been noted by A. Toffler and H. Toffler (1995, p. 72), "the relatively standard structures are being replaced by matrix-based organisations, adhocratic project teams, profit centres, as well as the growing variety of strategic alliances, joint ventures, and consortiums.". Hence in management science there appeared the numerous, although frequently fragmented, concepts 
explaining the nature of evolution of organisational systems. These included such models as the heterarchical organisation (Hedlund 1986), the multifocal organisation (Prahalad, Doz 1987), the horizontal organisation (White, Poynter 1990), or the kaleidoscopic organisation (Peters 1993). These concepts present the idea behind the creation of a cooperation network and stem from the rejection of the predominating, once-defined strategy (Hartman, Sifonis, Kador 2001, p. 14). For it has become irrational to prepare a one-direction action plan for the long term. Quite the contrary, it has become necessary to adopt short-term periods for strategy employment and to pursue several undertakings at the same time. This provides the organisation with the opportunity to change its business profile as its environment changes or whenever it finds a market niche (Krasiński, 2010, p. 26).

In view of the above, the most important feature of the management methods for organisations operating on the e-commerce market is hyperflexibility thanks to which the organisation can use foreign resources efficiently, easily adapt to new market conditions, or avoid the need for adaptive change by finding new markets or niches. The term hyperflexibility so far has not been defined in the literature. It is used intuitively. Since, in the second half of the $20^{\text {th }}$ century, organisations operating on competitive markets had to develop the ability to act flexibly, that is the ability to quickly implement changes in action, then the growing degree of complexity, unpredictability, and intermittence of events in the organisation's environment require the use of the hyper- suffix in order to emphasise a higher degree of such abilities.

Flexibility is a feature of a specific organisational form whose structure and modus operandi can easily transform. The degree of ease of such change depends of the characteristics of the human and technical resources and on the skills with which they can be employed in the management process. Contrary to the above, hyperflexibility pertains to the ease of creating new organisational forms in order to take advantage of the opportunities and avoid the pitfalls of the e-commerce market. Therefore flexibility may, for example, mean that a highly specialised employee acquires more polyvalent skills which enable them to perform a wider range of organisational tasks. In case of hyperflexibility such a change is not required of one's own employees, because their highly specialist skills can become very useful - instead, for the period when a new task needs to be finished one engages an employee who can best complete that task. Flexibility means also that organisational procedures can be swiftly adapted for the purpose of manufacturing a new product, whereas in case of hyperflexibility, the manufacturing is relocated to a site where the necessary procedures are already 
being followed. In case of flexibility, whenever sales fall on a given market, a search for solution is instigated within the organisation in order to accommodate new expectations of the customers. On the other hand, hyperflexibility implies that solutions are found in cooperation with other organisation or by moving the business operation onto a different market where the current product is going to sell better.

The degree of hyperflexibility undoubtedly depends on:

- information about the characteristics of the resources which are at the disposal of organisations operating in the same environment,

- the skills in reaching agreements aimed at forming temporary coalitions and alliances, i. e. cooperation networks for realisation of joint projects,

- skills in designing structures and action plans that enable the organisation to correctly use the features of their resources when completing a project.

A determinant of hyperflexibility is the potential of the partners who comprise the organisational network for the purpose of running various projects. This potential includes:

- the innovative potential - ideas, inventions, concepts,

- the human resources potential - expertise, skills, experience,

- the technical potential - the number, type, newness, and sophistication of the technical and technological means,

- the marketing potential - the knowledge of the market, the image, customer loyalty,

- the cultural potential - communication skills, trust, reliability, tolerance, and professionalism.

When creating an organisational network, hyperflexibility becomes apparent in that both the adoption of a strategy as well as the design of the structure are dominated by conjunction and not alternatives. Thinking in either-or categories is replaced by a this-and-that approach. At the same time, it is not just the spatial aspect, because, quite obviously, various areas of operation in a network organisation can differ considerably. It is primarily the temporal aspect, i.e. the ability to move easily and swiftly from one solution to another. In case of a structure this move is from centralisation to decentralisation and back, from specialisation to universalization and back, from a high degree of formality to a low degree and back. Whereas in case of a strategy - from concentration to diversification and back, from adaptation to expansion and back, and from integration to dispersion of activities and back. Only such organisational abilities, possible to acquire solely within a network that synergises the potential of different organisation, can be truly useful in a journey across various 
markets, created and discovered via e-commerce in the management process. It is only these features that can ensure the correct use of the arising technological possibilities and the subsequent opportunities on the e-commerce market, where hyperflexibility is the necessary condition for success.

\section{Cultural conditioning of hyperflexibility}

In their concept of organisational balance, A.K. Koźmiński and K. Obłój (1989, p. 286) classified four tools that are used to restore a relative organisational stability: structure, procedures, strategy, and organisational culture. A historical analysis of management methods over the last 100 years has led to the conclusion that the structure and procedures were the leading regulators at the peak of the industrial age. Stable and receptive markets encouraged businesses to focus on processes inside the organisation in order to increase productivity. In the second half of the $20^{\text {th }}$ century, the quick increase in competition on the markets brought forth strategy as the basic method for shaping relations with the surroundings and as a method for reacting quickly to the environmental changes. On the e-commerce market, everything seems to indicate that the dominant component is organisational culture which impacts the organisation's ability to use communication means, to establish effective cooperation without geographical restrictions, and to find clients. Paradoxically, in this technocratic, information age, the soft management tools seem to be of greatest importance. According to Bell's approach, at present the game is played between a human and another human, and the justification for such status quo is the precedence of cooperation and the need of innovation (Drahms, Woodside 2009, 7). The cultural potential of an organisation is the most important element as it is crucial for finding partners for a project and efficient management of this process. Therefore the cultural potential is the key to using other types of cooperation potential which is the subject of exchange between organisations.

Organisational culture, while conducive to success for organisations on the e-commerce market, it is also unique and differs considerably from cultural models which were popular in the past. It is a culture of pragmatism, based on the ideas of usefulness and changeability. These two assumptions are considered when choosing the specific values and norms and patterns of behaviour that will be followed at that time. Pragmatic cultures are oriented towards taking advantage of the opportunities created by network communication. They include a unique combination of collective and individualistic cultural patterns, but it would be quite difficult to find ideological references there. In pragmatic 
cultures, human behaviour is mainly the result of adaptation to situations assessed as beneficial here and now. The main characteristic of this culture is distributive identification. This type of identification can also be described as individualism in a collective. It is neither sacrificing oneself for the group nor focusing on one's own career model, but a sense of solidarity with each member of the group who have similar interests or are in a similar situation. Distributive identification arises when group members must rely on mutual cooperation if each of them wants to reach their objectives. This type of identification results from the formation of social groups for the purpose of realising undertakings which benefit all participants. Here, the subject of identification are people who share interests and who can help one another, and not a single, overriding idea they need to serve, as in the case of collective identification. Distributive identification is generally a less sustainable social bond than collective identification, because the opportunities and possibilities of mutual assistance are usually swiftly exhausted, and the paths of group members diverge.

An important feature of this culture is trust, which in the Internet economy is a prerequisite for effective trade. It is only the level of trust that enables one to differentiate one anonymous entity participating in trade from another (Hartman, Sifonis, Kador 2001, p. 144). Moreover, these cultures are dominated by a focus on the present. The dynamics of change and variety in the global environment mean that solutions used in the past seldom are useful in solving current problems. In turn, the above mentioned features of the environment make the future highly unpredictable. However, this does not imply that, in a given time and space, it would be impossible for such conditions to occur where a focus on the past or the future would not be necessary. People participating in this culture have no issues with such attitude to time. Being a part of a cooperation network also requires a unique combination of homogeneity and cultural heterogeneity. On the one hand, in a network culture, one strives to find shared norm and values, without which cooperation would be laborious or downright impossible. On the other hand, it is necessary to leave some autonomy to groups and individuals in terms of methods they employ to fulfil their tasks. The participants of a network may vary between one another in the degree of informality in their interpersonal relations or organisation of their work space. Their differences may stem from the industry where they work, the age of their employees and their personality traits, as well as the adopted strategy. However it should be noted that contact with such variety is also a stimulating factor for mutual development, innovation, and enables the organisations to build their knowledge resources. 
The most important change that the information age precipitated not only in organisational cultures but in our social culture in general was the change of attitude to identity. According to M. Castells (2001), there has been a shift from the legitimising identity, based on tradition, monocentric and homogenous, to a projecting identity which is heterogeneous, complex, and pluralistic. Above all however, in essence this means that the modern human being no longer has a single, fixed identity. As Z. Mach writes "the identity is fluid, unstable, and dialogic. We are entering new relations with new partners and we negotiate our identity with them while, at the same time, we participate in shaping of their identity. All that is social and cultural is fluid, momentary, and fragmentary." (Paleczny 2008, p. 14) In a multi-contextual, multi-cultural social space, in a spatially unrestricted e-commerce market, it is that approach to identity that facilitates the growth of pragmatic culture which is the foundation of hyperflexibility.

\section{Conclusion}

The conditions which determine the functioning of the e-commerce market are also a very interesting area for research. Due to its short history, there are still many issues worth studying, both for the theory as well as practice of management. One of these issues is hyperflexibility - a term that is appearing more and more frequently in studies devoted to describing the features of modern organisations and which is used intuitively to emphasise the non-linearity of organisational behaviour in turbulent surroundings. Therefore it is necessary to operationalize this term, to attempt to define its character.

Hyperflexibility is a feature of organisations which operate on the e-commerce market and whose domain is:

- undertaking of business ventures, motivated by cooperation in a cooperation network,

- the ability to implement various organisational solutions (strategic, structural) which will be most beneficial from the point of view of the current situation and the capacity for smooth change as well as the need arising from the changing situation,

- the pragmatic organisational culture that promotes trust as a primary value which is the basis for efficient functioning of an organisation in virtual space, and as a behavioural norm - focus on the present and individualism within the collective; an organisation that is able to maintain its inner coherence while remaining open to dissimilar behaviours of their co-operators. 
Identifying these features enables one to see the significant changes in the functioning of these organisations which opted for the e-commerce market as their place of operation. Subsequently a direction has been set for evolution of the subject of management - from a fixed organisational for to a temporary, project-oriented one, which emphasises the complexity and lack of uniformity in management processes within e-commerce organisations. These observations should encourage a new perspective in analysis of management - one where the linear dependencies will be rejected in favour of a more impressionist image in which individual points can be marked that will then form a unique whole. Empirical studies should also be conducted whose results would enable further observation of the evolution in management at the special stage of divergence on the market playing field into the traditional and the e-commerce market.

\section{Summary}

\section{Hyperflexibility. A feature of e-commerce organisations}

The paper is sacrificed analysis of conditions organizational activity on e-commerce business and desired ways of management. Organizations on e-commerce business must be hyper-flexible because of stormy environment and high level of competition. Hyperflexibility means ability to creating new organizational forms so as to realization of different projects collaboration with other organizations and utilizing strange resources. The main condition of Hyperflexibility is pragmatic organizational culture and such its attributes as confidence, tolerance and fluent identity.

Keywords: e-commerce, flexibility, organizational culture, pragmatism.

\section{Streszczenie}

Hiperelastyczność. Cecha organizacji na rynku e-commerce

Opracowanie poświęcone jest analizie warunków funkcjonowania organizacji na rynku e-commerce i związanym z tym sposobem zarządzania. Ze względu na burzliwość otoczenia i wysoki stopień konkurencyjności, organizacje na rynku e-commerce cechować musi hiperelastyczność. Hiperelastyczność polega na łatwości tworzenia nowych form organizacyjnych dla realizacji różnych projektów we współpracy $\mathrm{z}$ innymi organizacjami i wykorzystywaniu obcych zasobów. Głównym warunkiem hiperelastyczności jest pragmatyczna kultura organizacyjna oparta na zaufaniu, tolerancji i płynnej tożsamości. 


\section{Słowa}

kluczowe: e-commerce, hiperelastyczność, kultura organizacyjna, pragmatyzm.

\section{References}

1. Beer S. (1974), Designing Freedom, J. Wiley, New York.

2. Castells M. (2001), The Power of Identity, Blackwell Publisher, Cornwall.

3. Chrabowski P., Wiśniewska I., Nisztuk T. et al. (2015), E-commerce: Jak sprostać wyzwaniom dynamicznego rozwoju i stać się dominujacym graczem?, Fundacja im. Lesława A. Pagi, http://www.pi.gov.pl/PARPFiles/file/ news/20150306_RAPORT_

4. eCommerce_Think_Paga_FINAL.pdf access date: 25.03.2015.

5. Crozier M. (1993), Przesiębiorstwo na podstuchu, PWN, Warszawa.

6. D'aveni R.A. (2010), Hypercompetition, Simon \& Schuster.

7. Hartman A., Sifonis J., Kador J. (2001), E-biznes. Strategie biznesu w gospodarce internetowej, Wydawnictwo K.E. Liber s.c., Warszawa.

8. Hedlund G. (1986), The Hypermodern MNC: A Heterarchy?, Human Resources Management, No. 25.

9. Internauci 2014, Komunikat z badań Centrum Badania Opinii Społecznej, No. 82/2014, Warszawa, http://www.cbos.pl/SPISKOM. POL/2014/K_082_14.PDF, access date: 20.03.2015.

10. Krasiński M. (2010), Zarządzanie przez delegowanie uprawnień jako trzon koncepcji organizacji wirtualnej, Prace Naukowe Uniwersytetu Ekonomicznego we Wrocławiu, No. 137.

11. Kozielski R. (2012), Biznes nowych możliwości, Oficyna a Wolters Kluwer business, Warszawa.

12. Koźmiński A.K., Obłój. K. (1989), Zarys teorii równowagi organizacyjnej, Wydawnictwo Naukowe PWN, Warszawa.

13. Koźmiński A.K. (2004), Zarzązanie w warunkach niepezoności, Wyd. Naukowe PWN, Warszawa.

14. Koźmiński A.K. (2013), Polskie laboratorium zarzadzania, "Harvard Business Review Polska", No. 121.

15. Łoboda M., Mącik R. (eds.) (2005), Przedsiębiorczość internetowa, Wyd. UMCS, Lublin.

16. Majewski P. (2007), Czas na e-biznes. Jak myślisz, ile można zarobić na stronie www?, Wydawnictwo HELION, Gliwice.

17. Michalak J. (2012), Centra zaawansowanych ustug biznesowych jako wyraz trendów w strategii rozwoju współczesnych przedsiębiorstw, [in:] A. Stabryła (ed.), Strategie rozwoju organizacji, Mfiles.

18. Mróz K. (2015), Klienci e-commerce w Polsce-podsumowanie roku 2014, http:/ / sprawnymarketing.pl/klienci-e-commerce-w-polscepodsumowanie-roku-2014/, access date: 15.03.2015. 
19. Paleczny T. (1998), Socjologia tożsamości, Wyd. Krakowskiej Szkoły Wyższej im. Andrzeja Frycza-Modrzewskiego, Kraków.

20. Peters T. (1993), Liberation Management, Pan Books, London.

21. Peters T.J., Waterman R.H., Jr. (2006), In Search of Excellence: Lessons from America's Best-Run Companies, New York: Harper Business.

22. Prahalad C.K., Doz Y. (1987), The Multinational Mission: Balancing Local Demands and Global Vision, Free Press, New York.

23. Spencer D.W. (2004), IBM Software for E-Business on Demand: Business Transformation and the on Demand Software Infrastructure, Maximum Press.

24. Szymański G. (2013), Innowacje marketingowe w sektorze e-commerce, Wydawnictwo Politechniki Łódzkiej.

25. Świeboda P., Petru R. (2012), Przedsiębiorczość - Internet - wzrost. Klucz do nowej odstony polskiej modernizacji, demosEUROPA -Centrum Strategii Europejskiej, Warszawa.

26. Toffler A., Toffler H. (1995), Budowa nowej cywilizacji. Polityka trzeciej fali, Wydawnictwo Zysk i Ska, Poznań.

27. Trompenaars F., Hampden-Turner Ch. (2002), Siedem wymiarów kultury. Znaczenie różnic kulturowych w działalności gospodarczej, Oficyna Ekonomiczna, Kraków.

28. White R.E., Poynter T.A. (1990), Organizing for Worldwide Advantage, in: Managing the Global Firm, Routledge, New York.

29. Żurak-Owczarek C. (2013), E-biznes w wymiarze globalnym i lokalnym. Analiza i próba oceny, Wydawnictwo Uniwersytetu Łódzkiego, Łódź. 